\title{
Effect of Antimicrobial Edible Films on the Sensory and Physical Properties of Organic Spinach in Salad Bags
}

\author{
Kamini Joshi',2, Patricia Sparks', Mendel Friedman', \\ Carl Olsen ${ }^{4}$, Tara McHugh", Sadhana Ravishankar ${ }^{1 *}$ \\ ${ }^{1}$ School of Animal and Comparative Biomedical Sciences, University of Arizona, Tucson, AZ, USA \\ ${ }^{2}$ Accelerate Diagnostics, Tucson, AZ, USA \\ ${ }^{3}$ Department of Nutritional Sciences, University of Arizona, Tucson, AZ, USA \\ ${ }^{4}$ USDA-ARS-Western Regional Research Center, Healthy Processed Foods Research, Albany, CA, USA \\ Email: *sadhravi@arizona.edu
}

How to cite this paper: Joshi, K., Sparks, P., Friedman, M., Olsen, C., McHugh, T. and Ravishankar, S. (2021) Effect of Antimicrobial Edible Films on the Sensory and Physical Properties of Organic Spinach in Salad Bags. Food and Nutrition Sciences, 12, 176-193.

https://doi.org/10.4236/fns.2021.122015

Received: December 29, 2020

Accepted: February 23, 2021

Published: February 26, 2021

Copyright $\odot 2021$ by author(s) and Scientific Research Publishing Inc. This work is licensed under the Creative Commons Attribution International License (CC BY 4.0).

http://creativecommons.org/licenses/by/4.0/

\begin{abstract}
The effects of antimicrobial edible films containing carvacrol and cinnamaldehyde on organic baby spinach were determined via sensory analysis and changes in physical properties. Edible films made from pulp of hibiscus, apple, or carrot containing carvacrol or cinnamaldehyde at $0.5 \%, 1.5 \%$, or $3 \%$ concentrations were added to organic baby spinach in plastic bags. These bags were stored at $4^{\circ} \mathrm{C}$ for $20-24 \mathrm{~h}$ before performing sensory evaluation and measuring changes in physical properties. A randomized block design with an affective test was used. Preference liking was evaluated based on a 9-point hedonic scale for aroma, color, freshness, mouthfeel, flavor, and overall acceptability. Additionally, panelists quantified each sample using a 5-point hedonic scale for pungency, browning, bitterness, off-odor, and sourness. The color and texture of spinach samples were measured. Edible films containing cinnamaldehyde had the highest preference liking based on aroma, color, freshness, mouthfeel, flavor, and overall acceptability than those containing carvacrol and were the most likely to be purchased by panelists; therefore, cinnamaldehyde can potentially be used as an alternative sanitization option. There were no significant $(\mathrm{p} \leq 0.05)$ changes in firmness or color values between spinach treated with antimicrobial films and controls. The results provide the produce industry with options for incorporating antimicrobial films into salad bags without influencing the physical or sensory properties of baby spinach.
\end{abstract}

\section{Keywords}

Edible Films, Plant Antimicrobials, Sensory Analysis, Organic Baby Spinach, 
Texture Analysis, Color Measurements

\section{Introduction}

Multiple studies have suggested the use of plant-based antimicrobials in food to prevent the growth of pathogenic bacteria. Burt [1] has discussed the antimicrobial properties of the active components of various essential oils such as carvacrol (oregano oil), thymol (thyme), eugenol (clove bud oil), perillaldehyde (perilla), cinnamaldehyde (cinnamon oil) and cinnamic acid in vitro and in foods. Additionally, essential oils (EOs) of oregano, thyme, cinnamon, clove bud, and allspice as well as their active components showed antimicrobial activities against Listeria monocytogenes, Escherichia coli O157:H7, and Salmonella enterica in vitro [2]. However, some of these compounds may adversely affect the sensory properties of foods. Therefore, careful selection of food-compatible plant antimicrobials on food types is necessary to avoid undesirable organoleptic effects.

Studies have looked at the effects of plant-derived antimicrobials on the organoleptic properties of different food types. For example, treatment with $1 \mathrm{mM}$ carvacrol or cinnamic acid showed no significant adverse effects on the organoleptic attributes of kiwi fruits and honeydew melons [3]. The addition of oregano oil to extra virgin olive oil maintained the positive attributes (fruity, pungency, bitterness and oregano flavor) during 21 days of storage at $23^{\circ} \mathrm{C}$ [4]. An addition of $0.1 \%$ oregano oil or thyme oil provided desirable odor and taste characteristics to lamb meat [5]. Gutierrez, et al. [6] have suggested that a combination of essential oils could help minimize the concentration of each and thus reduce the adverse sensory impacts in food.

There are two ways in which plant antimicrobials can be added to foods: (a) adding antimicrobials directly to food; and (b) incorporating the antimicrobials in edible films, which are then used to wrap the foods or added as an ingredient [7]. Edible films are thin layers of food-based material which can be consumed and provide a barrier to moisture, oxygen, and solute movement of food [8]. Another major advantage of edible films is that these films may enhance the organoleptic properties of a food product because they could have various components (flavoring, coloring, and sweeteners) which may be desirable to consumers. Edible films can be used as a carrier for antioxidants, flavoring agents, coloring agents, and antimicrobials to extend the shelf-life and to improve food quality [9] [10] [11] [12] [13]. Another advantage of edible films is that they can replace plastic packaging with biodegradable materials which will lead to a reduction in overall packaging and waste disposal [14]. The major food commodities that could potentially be used with edible films include meat, fish, poultry, bread, cheese, fruits and vegetables [15].

Previous studies in our laboratory have indicated the efficacy of plant-based 
antimicrobials against foodborne pathogens in foods. Oregano oil at $0.1 \%-0.5 \%$ showed 1 - $4.7 \mathrm{log}$ CFU/g reduction in Salmonella Newport population on organic baby spinach within $24 \mathrm{~h}$ [16]. Treatment with $0.1 \%-0.5 \%$ cinnamon oil showed $0.5-2.5 \log$ CFU/g reduction in $S$. Newport population within $24 \mathrm{~h}$ on organic baby spinach [17]. Essential oils can improve the microbial safety of food; however they should not have a negative impact on sensory properties which may influence their acceptance by the consumers [18].

Studies have shown that edible films can improve shelf-life and food quality serving as barriers for moisture loss, oxygen uptake, lipid oxidation, and enhancing aroma and flavors in food [19]. Other studies have indicated that films made from apple consisting of essential oils (oregano, cinnamon, and lemongrass) and their active components (carvacrol, cinnamaldehyde, and citral) showed antimicrobial activity against E. coli $\mathrm{O} 157: \mathrm{H} 7$ in vitro [20] [21]. Ham and bologna wrapped with edible films made from apple, hibiscus, and carrot pulp containing 3\% carvacrol showed 2 - $3 \log$ CFU/g reduction in L. monocytogenes within 7 days of storage at $4^{\circ} \mathrm{C}$ [22]. The use of edible films may be more appropriate on fresh produce as higher reduction of foodborne pathogens is observed on leafy greens in comparison to meat products. Edible films containing $3 \%$ carvacrol showed $5 \log$ CFU/g reduction by day 0 against Salmonella in organic leafy greens in plastic salad bags [23]. Similar reductions against E. coli were observed in sealed plastic salad bags [24].

Higher concentrations of essential oils may be required for better antimicrobial activity; however, this may lead to unpleasant odor or flavor [6]. Tomato juice and vegetable soup had higher preference liking than control when incorporated with $20 \mu \mathrm{L} / \mathrm{L}$ of pennyroyal mint essential oil or rosemary essential oil, respectively, but the preference liking decreased by $15 \%-20 \%$ when the concentration of essential oils was increased to $100 \mu \mathrm{L} / \mathrm{L}$ [25]. A combination treatment can be effective in order to maintain a balance between sensory acceptability and antimicrobial efficacy. Sub-lethal concentrations of carvacrol and 1,8-cineole (1/8 MIC + 1/8 MIC) improved the majority of sensory attributes of vegetables (iceberg lettuce, chard, and arugula) after wash and refrigerated storage compared to vegetables sanitized with either of these compounds alone (at the MIC) [26]. Innovative methods need to be investigated where essential oils may be applied in food products indirectly without having adverse effects on the organoleptic properties. Therefore, in this study, we determined preference liking of baby spinach treated with antimicrobial edible films.

The use of essential oils and plants extracts directly may have adverse effects on the organoleptic properties of leafy greens. To minimize the impact of plant antimicrobials on sensory properties, they can be incorporated into edible films. The objectives of this study were a) to determine the effect of antimicrobial edible films on the sensory properties of organic baby spinach by evaluating using a 40-member sensory panel and b) to evaluate the impact of these films on the color and texture of treated organic baby spinach in salad bags. 


\section{Materials and Methods}

\subsection{Edible Films Used}

Edible films used in this study include hibiscus, carrot, and apple-based films. Each film type was incorporated with one of the following concentrations of essential oils: $0.5 \%, 1.5 \%$, and $3 \%$ of carvacrol or cinnamaldehyde. In each type, control films without any antimicrobials were also included in each experiment.

\subsection{Edible Films Preparation}

Edible films were made from hibiscus, apple, or carrot pulp. The films contained vegetable or fruit puree, high methoxy pectin (3\%), vegetable glycerin, citric acid, and ascorbic acid. The film-forming solution was made by blending high methoxy pectin solution, fruit or vegetable puree, and vegetable glycerin into a mixer for 15 $\mathrm{min}$ at low speed. The solution was mixed again for $45 \mathrm{~min}$ at low speed after adding citric and ascorbic acids with a total mixing time of $60 \mathrm{~min}$. The film solution $(325 \mathrm{~g}$ ) was then equally divided into seven $600 \mathrm{ml}$ stainless steel beakers and refrigerated. The following concentrations of carvacrol or cinnamaldehyde were added to a beaker: $0.5 \%$ (1.63 g), 1.5\% (4.95 g), and 3\% (10.05 g), and one beaker for control (no antimicrobials added). The samples were homogenized at refrigeration temperature on the Brinkman Polytron PT3000 (Brinkman Instruments Inc., N.Y., USA) for $3.5 \mathrm{~min}$ between 20,000 and $24,000 \mathrm{rpm}$ using a probe that was $20 \mathrm{~mm}$ in diameter. The film solution $(58-61 \mathrm{~g})$ was then placed on a polyester (PET) film and casted using a draw down bar. Films were then allowed to dry on a lab bench at room temperature $\left(23^{\circ} \mathrm{C}-25^{\circ} \mathrm{C}\right)$ for $14 \mathrm{~h}$. Films were then cut into pieces by using a single edge razor. Edible films were made at the USDA-ARS-WRRC facility in Albany, California, USA. A detailed description for casting edible films has been described in our previous publication [22].

\subsection{Treatment of Bagged Spinach with Edible Films}

Organic baby spinach was purchased from the retail store the same day the treatment was performed. Organic baby spinach was washed thoroughly with tap water and air-dried at room temperature. Between 50 and $70 \mathrm{~g}$ of spinach was packed in plastic Ziploc ${ }^{\circledR}$ bags. In each bag, one type of antimicrobial edible film (hibiscus, apple or carrot-based; containing either carvacrol or cinnamaldehyde at $0.5 \%, 1.5 \%$ or $3 \%$ ) or a control type of film cut into small pieces was added at $3 \%(\mathrm{w} / \mathrm{w})$ and mixed well with the bag contents. Salad bags containing edible films were stored at $4^{\circ} \mathrm{C}$ for $20-24 \mathrm{~h}$ prior to performing sensory analysis and measuring changes in color or texture.

\subsection{Sensory Analysis}

Sensory analysis was performed using 40 untrained panelists during each trial. A total of 4 trials (160 panelists in all trials together) were conducted. At each trial, 40 panelists evaluated 5 or 6 different samples (including a control) at a time. One gram of each sample was given to the panelists and after each sample, panelists 
were asked to drink water and wait for at least 2 min prior to evaluating the next sample. Panelists were asked to evaluate each sample based on a 9-point hedonic scale where $9=$ like extremely, $8=$ like very much, $7=$ like moderately, $6=$ like slightly, 5 = neither like nor dislike, 4 = dislike slightly, 3 = dislike moderately, $2=$ dislike very much, 1 = dislike extremely. Sensory parameters were evaluated based on preference liking for aroma, color, freshness, mouthfeel, flavor, and overall acceptability. A randomized block design with an affective test was conducted to generate data for preference liking. Panelists quantified each sample for sensory characteristics on the basis of pungency, browning, bitterness, off-odor, and sourness. Sensory characteristics were evaluated using a 5-point hedonic scale, where 1 would be rated the lowest and 5 would be rated the highest $(1=$ not pungent, $2=$ slightly pungent, $3=$ moderately pungent, $4=$ very pungent, $5=$ extremely pungent).

Sensory analysis was conducted at the University of Arizona-Department of Nutritional Sciences in sensory booths with constant yellow light. Panelists also answered questions about demographics such as age, gender, ethnicity, frequency of consumption of organic/conventionally grown leafy greens, and types of leafy greens preferred or purchased the most prior to treatment (iceberg lettuce, romaine lettuce, spinach, or mixed greens).

\subsection{Texture Analysis}

The texture of each spinach sample was measured using a Texture Lab Pro, Food Technology Corporation (Sterling, VA, USA). A $1000 \mathrm{~N}$ load cell was attached to a Kramer shear cell with an 8-blade probe attached to the instrument [27]. The speed for the experiment was set to $250 \mathrm{~mm} \cdot \mathrm{min}^{-1}$. A sample of $15 \mathrm{~g}$ of baby spinach with edible films was placed in the Kramer cell and the 8-blade probe was used to crush the sample to measure firmness. Three readings of the same samples were taken, and an average of the highest peak force was indicated as the crispiness value for each sample evaluated.

\subsection{Color Measurements}

The color of the spinach samples was measured using a Minolta Chroma Meter (Model CR-400, Minolta, Inc., Tokyo, Japan). The color was measured using the CIE L ${ }^{*}, \mathrm{a}^{*}$, and $\mathrm{b}^{*}$ coordinates. Illuminant D65 and $10^{\circ}$ observer angle was used [28]. The instrument was calibrated using the Minolta standard white reflector plate. The $L^{*}$ value is the measurement of lightness from dark $\left(L^{*}=0\right)$ to absolute light $\left(L^{*}=100\right)$, the $a^{*}$ axis ranges from green $(-)$ to red $(+)$ and $b^{*}$ axis ranges from blue $(-)$ to yellow $(+)$ [29]. Three different readings were taken during each repeat and each experiment was repeated three times, providing a total of 9 readings for each sample.

\subsection{Statistical Analysis}

For sensory analysis, each experiment was divided into four trials with new sets 
of 40 panelists at each trial (total of 160 panelists), who evaluated 5 to 6 samples. Randomized block design was used for sensory analysis. A linear regression was used to determine the correlation between overall acceptability and other sensory parameters based on preference liking by the panelists. Statistical analysis for each study (sensory, texture measurements, and color measurements) was conducted by One-way Analysis of variance (ANOVA) Tukey's pairwise test at a level of significance of $\mathrm{p} \leq 0.05$ using Minitab 17 (State College, PA, USA). Comparison of significance was made between the various types of films and between the various concentrations of antimicrobials within each type of film.

\section{Results and Discussion}

Edible films containing various concentrations $(0.5 \%, 1.5 \%$ and $3.0 \%)$ of carvacrol and cinnamaldehyde were added into bagged baby spinach $(3 \% \mathrm{w} / \mathrm{w})$ that was stored at $4^{\circ} \mathrm{C}$ for $20-24 \mathrm{~h}$ prior to evaluation by panelists. At these concentrations and storage time, previous studies have indicated the antimicrobial properties of edible films in baby spinach bags. Zhu, Olsen, McHugh, Friedman, Jaroni and Ravishankar [23] have shown that apple, carrot, and hibiscus films containing 3\% carvacrol or cinnamaldehyde demonstrated 5 - 6 logs reduction in the population of $S$. Newport and E. coli O157:H7 in bagged baby spinach soon after treatment. These edible films may enhance or reduce the acceptability of the product based on sensory attributes. Incorporating a high level of apple skin polyphenols in edible films is known to adversely affect the palatability of edible films by inducing astringency or bitterness [30]. On the other hand, coatings may provide a glossy appearance on the food surface which may help improve the visual quality of food [31]. Therefore, research needs to be conducted to identify formulations of the antimicrobials that will be preferred by panelists.

\subsection{Demographic Information}

The criteria for panelists to participate in this study included the following: a) each panelist must be at least 18 years or older, b) must be a non-smoker, and c) be able to differentiate between colors. Demographic results are depicted in Figure 1. A total of 160 panelists participated in this study of which $88 \%$ were female, and $12 \%$ were male. The age of the panelists ranged from 18 to 55 years with the majority of the population (89\%) falling in the age range of $18-25$ years. Based on ethnicity, panelists included 47\% White, 29\% Hispanic, 9\% Asian, 3\% African American, and 12\% others. Each panelist was asked to indicate the type of leafy greens they consume/purchase the most and the following results were noted: $34 \%$ mixed greens, $32 \%$ spinach, $22 \%$ romaine, and $11 \%$ iceberg lettuce. Panelists also indicated the frequency of consumption of leafy greens and $45 \%$ indicated that they consume conventional leafy greens twice a week and $13 \%$ indicated consumption of organic leafy greens twice a week.

\subsection{Sensory Analysis}

The results from the sensory analysis of organic baby spinach treated with edible 
(a)
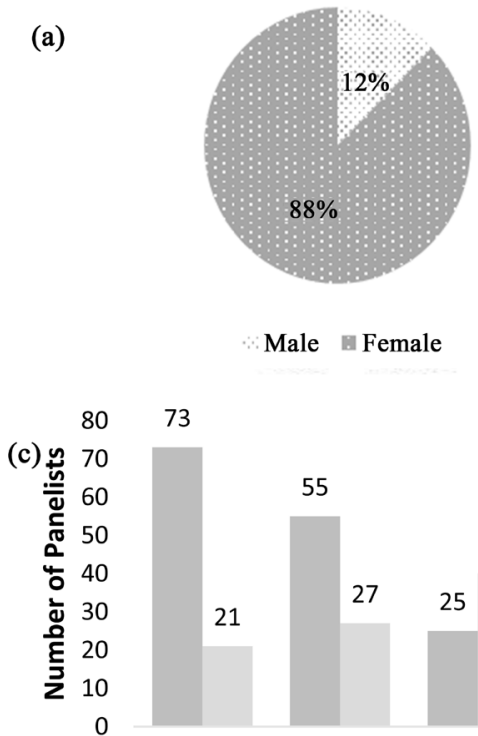

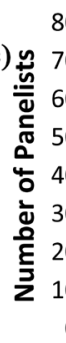

73

55

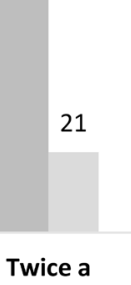

55

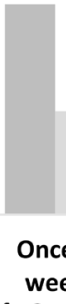

week

Conventional Leafy Greens

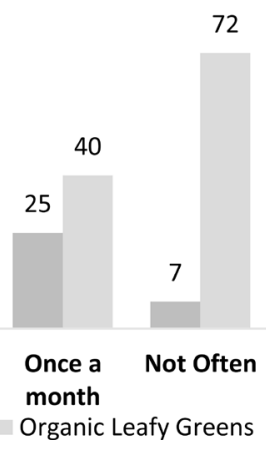

(b)

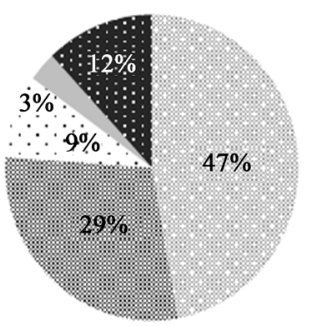

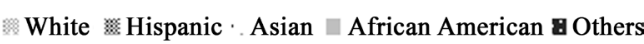

(d)

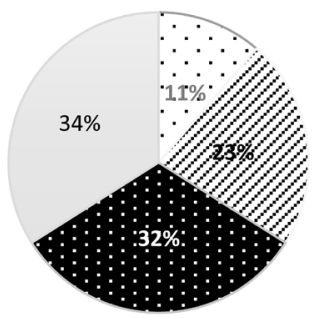

$\square$ Iceberg $*$ Romaine Spinach $\square$ Mixed Green

Figure 1. Demographic information regarding panelists who participated in the sensory study for evaluating spinach from salad bags containing antimicrobial edible films. Data depicts responses from a total of 160 participants. (a) Gender ratio (b) Ethnicity ratio (c) Pattern for consumption of leafy greens and (d) Preference for type of leafy greens.

films are presented in Table 1 and Table 2. Previous studies conducted in our lab showed that spinach washed with essential oils had higher preference liking by consumers in comparison to iceberg lettuce [32]. Additionally, demographic information indicated that panelists had higher preference liking for spinach than the lettuces (Figure 1(d)). Therefore, in this study we conducted sensory analysis of organic baby spinach treated with edible films. Our previous studies also indicated that leafy greens treated with cinnamon oil had the highest preference liking. Therefore, in this study we selected carvacrol and cinnamaldehyde, as previously these compounds have been known to be acceptable by consumers and have shown antimicrobial activity. Based on the preference liking by consumers, spinach treated with edible films had ratings from $7.1 \pm 1.7$ (moderately liked for apple-control film) to $3.6 \pm 2.5$ (moderately disliked-apple-1.5\% carvacrol film).

Overall edible films incorporated with cinnamaldehyde had higher preference liking based on aroma, color, freshness, mouthfeel, flavor, and overall acceptability than those incorporated with carvacrol (Table 1; Figure 2). Our previous studies also support this result because spinach washed with $0.1 \%$ cinnamon oil had higher preference liking in comparison to that washed with $0.1 \%$ oregano oil [32]. A concentration-dependent activity was observed: a higher preference liking was seen in edible films with lower concentration of either carvacrol or cinnamaldehyde. For example, carrot film with $0.5 \%$ cinnamaldehyde had a preference liking of $6.6 \pm 2.3$ (slightly liked), whereas carrot film with $3 \%$ cinnamaldehyde had a rating of $5.9 \pm 2.5$ (neither liked nor disliked). 
Table 1. Preference liking of spinach treated with antimicrobial edible films and stored at $4^{\circ} \mathrm{C}$ for 24 hrs. Data shown is an average of responses from 40 panelists for each sample \pm standard deviation. Values that do not share common letters are significantly different $(\mathrm{p} \geq 0.05)$.

\begin{tabular}{|c|c|c|c|c|c|c|}
\hline Sample\# & Aroma & Color & Freshness & Mouthfeel & Flavor & Overall acceptability \\
\hline Apple-Control & $6.6 \pm 1.8^{\mathrm{ABC}}$ & $7.9 \pm 1.4^{\mathrm{A}}$ & $7.6 \pm 1.6^{\mathrm{A}}$ & $7.2 \pm 1.8^{\mathrm{A}}$ & $7.1 \pm 1.9^{\mathrm{A}}$ & $7.1 \pm 1.7^{\mathrm{A}}$ \\
\hline Hibiscus-Control & $6.8 \pm 1.7^{\mathrm{AB}}$ & $7.6 \pm 1.5^{\mathrm{AB}}$ & $7.4 \pm 1.7^{\mathrm{AB}}$ & $7.0 \pm 1.9^{\mathrm{AB}}$ & $6.7 \pm 2.0^{\mathrm{AB}}$ & $7 \pm 1.8^{\mathrm{AB}}$ \\
\hline Carrot- $0.5 \%$ Cinnamaldehyde & $5.8 \pm 2.2^{\mathrm{ABCD}}$ & $7.1 \pm 1.8^{\mathrm{ABC}}$ & $6.7 \pm 2.1^{\mathrm{ABCD}}$ & $6.8 \pm 1.7^{\mathrm{AB}}$ & $6.6 \pm 2.0^{\mathrm{ABC}}$ & $6.6 \pm 2.3^{\mathrm{ABC}}$ \\
\hline Apple- $0.5 \%$ Cinnamaldehyde & $7.1 \pm 1.8^{\mathrm{A}}$ & $7.1 \pm 1.8^{\mathrm{ABC}}$ & $6.5 \pm 2.1^{\mathrm{ABCD}}$ & $6.5 \pm 2.2^{\mathrm{ABCD}}$ & $6.3 \pm 2.2^{\mathrm{ABCD}}$ & $6.4 \pm 2.1^{\mathrm{ABC}}$ \\
\hline Carrot-0.5\% Carvacrol & $6.0 \pm 2.0^{\mathrm{ABCD}}$ & $7.2 \pm 1.7^{\mathrm{ABC}}$ & $6.7 \pm 2.0^{\mathrm{ABCD}}$ & $6.6 \pm 1.9^{\mathrm{ABC}}$ & $6.1 \pm 2.2^{\mathrm{ABCDE}}$ & $6.3 \pm 2.1^{\mathrm{ABC}}$ \\
\hline Carrot-Control & $6.5 \pm 1.8^{\mathrm{ABCD}}$ & $7.5 \pm 1.5^{\mathrm{ABC}}$ & $7.7 \pm 1.6^{\mathrm{A}}$ & $7.1 \pm 1.8^{\mathrm{AB}}$ & $5.8 \pm 2.5^{\mathrm{ABCDEF}}$ & $6.2 \pm 2.3^{\mathrm{ABC}}$ \\
\hline Hibiscus $0.5 \%$ Cinnamaldehyde & $6.6 \pm 1.8^{\mathrm{ABC}}$ & $7.2 \pm 2.0^{\mathrm{ABC}}$ & $6.7 \pm 2.3^{\mathrm{ABCD}}$ & $6.6 \pm 2.0^{\mathrm{ABC}}$ & $6.0 \pm 2.3^{\mathrm{ABCDE}}$ & $6.2 \pm 2.2^{\mathrm{ABCD}}$ \\
\hline Apple-3\% Cinnamaldehyde & $6.8 \pm 2.2^{\mathrm{AB}}$ & $6.9 \pm 1.8^{\mathrm{ABC}}$ & $6.4 \pm 2.1^{\mathrm{ABCD}}$ & $6.4 \pm 2.1^{\mathrm{ABCD}}$ & $5.8 \pm 2.7^{\mathrm{ABCDEF}}$ & $6.0 \pm 2.3^{\mathrm{ABCDE}}$ \\
\hline Carrot-3\% Cinnamaldehyde & $6.8 \pm 1.8^{\mathrm{AB}}$ & $7.5 \pm 1.6^{\mathrm{ABC}}$ & $7.2 \pm 1.6^{\mathrm{ABC}}$ & $6.6 \pm 2.0^{\mathrm{ABCD}}$ & $5.4 \pm 2.5^{\mathrm{ABCDEFG}}$ & $5.9 \pm 2.5^{\mathrm{ABCDE}}$ \\
\hline Apple-1.5\% Cinnamaldehyde & $6.8 \pm 1.6^{\mathrm{AB}}$ & $8.0 \pm 1.3^{\mathrm{A}}$ & $7.5 \pm 1.3^{\mathrm{AB}}$ & $6.8 \pm 2.0^{\mathrm{AB}}$ & $5.5 \pm 2.7^{\mathrm{ABCDEF}}$ & $5.9 \pm 2.6^{\mathrm{ABCDE}}$ \\
\hline Carrot-1.5\% Cinnamaldehyde & $5.6 \pm 2.1^{\mathrm{ABCD}}$ & $7.2 \pm 2.0^{\mathrm{ABC}}$ & $7.1 \pm 2.1^{\mathrm{ABC}}$ & $6.2 \pm 2.4^{\mathrm{ABCD}}$ & $5.6 \pm 2.5^{\mathrm{ABCDEF}}$ & $5.7 \pm 2.2^{\mathrm{ABCDE}}$ \\
\hline Hibiscus-1.5\% Cinnamaldehyde & $6.9 \pm 1.8^{\mathrm{A}}$ & $7.3 \pm 2.0^{\mathrm{ABC}}$ & $7.5 \pm 1.5^{\mathrm{AB}}$ & $6.6 \pm 2.2^{\mathrm{ABC}}$ & $5.4 \pm 5.4^{\mathrm{ABCDEFG}}$ & $5.7 \pm 2.6^{\mathrm{ABCDE}}$ \\
\hline Apple- $0.5 \%$ Carvacrol & $6.1 \pm 2.3^{\mathrm{ABCD}}$ & $6.7 \pm 1.9^{\mathrm{ABC}}$ & $6.4 \pm 2.1^{\mathrm{ABCD}}$ & $6.1 \pm 2.3^{\mathrm{ABCD}}$ & $5.2 \pm 2.6^{\mathrm{ABCDEFG}}$ & $5.6 \pm 2.2^{\mathrm{ABCDE}}$ \\
\hline Hibiscus-0.5\% Carvacrol & $5.6 \pm 2.0^{\mathrm{ABCD}}$ & $6.9 \pm 1.9^{\mathrm{ABC}}$ & $6.6 \pm 2.1^{\mathrm{ABCD}}$ & $5.6 \pm 2.3^{\mathrm{ABCD}}$ & $5.2 \pm 2.5^{\mathrm{ABCDEFG}}$ & $5.1 \pm 2.4^{\mathrm{BCDEF}}$ \\
\hline Hibiscus-3\% Cinnamaldehyde & $6.3 \pm 2.5^{\mathrm{ABCD}}$ & $6.7 \pm 2.2^{\mathrm{ABC}}$ & $6.5 \pm 2.3^{\mathrm{ABCD}}$ & $6 \pm 2.6^{\mathrm{ABCD}}$ & $5 \pm 3.0^{\mathrm{BCDEFG}}$ & $5.1 \pm 2.9^{\mathrm{CDEF}}$ \\
\hline Carrot-1.5\% Carvacrol & $5.5 \pm 5.5^{\mathrm{ABCD}}$ & $6.9 \pm 1.8^{\mathrm{ABC}}$ & $6.8 \pm 1.7^{\mathrm{ABCD}}$ & $6.4 \pm 1.9^{\mathrm{ABCD}}$ & $4.5 \pm 2.6^{\mathrm{DEFG}}$ & $4.8 \pm 2.5^{\mathrm{CDEF}}$ \\
\hline Apple-3\% Carvacrol & $5.6 \pm 2.5^{\mathrm{ABCD}}$ & $6.1 \pm 2.3^{\mathrm{BC}}$ & $5.7 \pm 2.5^{\mathrm{CD}}$ & $5.3 \pm 3.0^{\mathrm{BCD}}$ & $4.5 \pm 3.0^{\mathrm{DEFG}}$ & $4.7 \pm 2.8^{\mathrm{CDEF}}$ \\
\hline Hibiscus 3\% Carvacrol & $5.5 \pm 2.3^{\mathrm{ABCD}}$ & $6.3 \pm 2.6^{\mathrm{BC}}$ & $5.9 \pm 2.4^{\mathrm{BCD}}$ & $5.7 \pm 2.5^{\mathrm{ABCD}}$ & $4.6 \pm 2.7^{\mathrm{CDEFG}}$ & $4.7 \pm 2.8^{\mathrm{CDEF}}$ \\
\hline Carrot-3\% Carvacrol & $5.0 \pm 2.5^{\mathrm{CD}}$ & $6.1 \pm 2.3^{\mathrm{BC}}$ & $5.3 \pm 2.5^{\mathrm{D}}$ & $4.7 \pm 2.8^{\mathrm{D}}$ & $4.1 \pm 2.6^{\mathrm{EFG}}$ & $4.2 \pm 2.6^{\mathrm{DEF}}$ \\
\hline Hibiscus-1.5\% Carvacrol & $5.2 \pm 2.4^{\mathrm{BCD}}$ & $6.7 \pm 2.0^{\mathrm{ABC}}$ & $6.4 \pm 2.4^{\mathrm{ABCD}}$ & $5.3 \pm 2.6^{\mathrm{BCD}}$ & $3.8 \pm 2.6^{\mathrm{FG}}$ & $4.2 \pm 2.5^{\mathrm{EF}}$ \\
\hline Apple-1.5\% Carvacrol & $4.8 \pm 2.7^{\mathrm{D}}$ & $6.1 \pm 2.4^{\mathrm{C}}$ & $5.7 \pm 2.5^{\mathrm{CD}}$ & $4.9 \pm 2.4^{\mathrm{CD}}$ & $3.5 \pm 2.5^{\mathrm{G}}$ & $3.6 \pm 2.5^{\mathrm{F}}$ \\
\hline
\end{tabular}

Table 2. Impact on the sensory characteristics of spinach treated with antimicrobial edible films and stored at $4^{\circ} \mathrm{C}$ for $24 \mathrm{~h}$. Each treatment was evaluated by 40 panelists and data depicted is an average \pm Standard Deviation. Same letters next to each value indicate that there is no significant difference $(\mathrm{p} \leq 0.05)$.

\begin{tabular}{|c|c|c|c|c|c|}
\hline Sample\# & Pungency & Browning & Bitterness & Off-Odor & Sourness \\
\hline Hibiscus-Control & $1.3 \pm 0.6^{\mathrm{H}}$ & $1.1 \pm 0.3^{\mathrm{D}}$ & $1.7 \pm 0.8^{\mathrm{EF}}$ & $1.3 \pm 0.7^{\mathrm{H}}$ & $1.5 \pm 0.8^{\mathrm{C}}$ \\
\hline Carrot-Control & $1.3 \pm 0.6^{\mathrm{GH}}$ & $1.2 \pm 0.6^{\mathrm{CD}}$ & $2 \pm 1.1^{\mathrm{BCDEF}}$ & $1.4 \pm 0.6^{\mathrm{GH}}$ & $1.7 \pm 0.8^{\mathrm{BC}}$ \\
\hline Apple- $0.5 \%$ Cinnamaldehyde & $1.4 \pm 0.7^{\mathrm{GH}}$ & $1.3 \pm 0.5^{\mathrm{ABCD}}$ & $1.5 \pm 0.8 \mathrm{~F}$ & $1.3 \pm 0.6^{\mathrm{H}}$ & $1.3 \pm 0.6^{\mathrm{C}}$ \\
\hline Apple-Control & $1.5 \pm 0.6^{\mathrm{GH}}$ & $1.1 \pm 0.4^{\mathrm{D}}$ & $1.6 \pm 1.0 \mathrm{~F}$ & $1.3 \pm 0.5^{\mathrm{H}}$ & $1.6 \pm 0.8^{\mathrm{BC}}$ \\
\hline Carrot- $0.5 \%$ Carvacrol & $1.6 \pm 0.8^{\mathrm{FGH}}$ & $1.5 \pm 0.7^{\mathrm{ABCD}}$ & $1.6 \pm 0.9^{\mathrm{F}}$ & $1.6 \pm 0.9^{\mathrm{FGH}}$ & $1.3 \pm 0.5^{\mathrm{C}}$ \\
\hline Hibiscus $0.5 \%$ Cinnamaldehyde & $1.6 \pm 0.8^{\mathrm{FGH}}$ & $1.3 \pm 0.6^{\mathrm{ABCD}}$ & $2.1 \pm 1.2^{\mathrm{BCDEF}}$ & $1.5 \pm 0.8^{\mathrm{GH}}$ & $1.8 \pm 1.1^{\mathrm{ABC}}$ \\
\hline Carrot-0.5\% Cinnamaldehyde & $1.8 \pm 1.1^{\mathrm{EFGH}}$ & $1.3 \pm 0.5^{\mathrm{BCD}}$ & $1.6 \pm 1.1^{\mathrm{F}}$ & $1.8 \pm 1.1^{\mathrm{EFGH}}$ & $1.6 \pm 1.1^{\mathrm{BC}}$ \\
\hline Carrot-1.5\% Cinnamaldehyde & $2.1 \pm 1.1^{\mathrm{DEFGH}}$ & $1.5 \pm 0.7^{\mathrm{ABCD}}$ & $1.8 \pm 1.1^{\mathrm{DEF}}$ & $2.1 \pm 1.2^{\mathrm{CDEFGH}}$ & $1.9 \pm 1.2^{\mathrm{ABC}}$ \\
\hline Hibiscus- $0.5 \%$ Carvacrol & $2.1 \pm 1.0^{\mathrm{DEFGH}}$ & $1.4 \pm 0.6^{\mathrm{ABCD}}$ & $2.1 \pm 1.3^{\mathrm{BCDEF}}$ & $2.3 \pm 12^{\mathrm{BCDEFG}}$ & $2.1 \pm 1.4^{\mathrm{ABC}}$ \\
\hline
\end{tabular}




\section{Continued}

\begin{tabular}{|c|c|c|c|c|c|}
\hline Apple- $0.5 \%$ Carvacrol & $2.2 \pm 1.3^{\mathrm{CDEFGH}}$ & $1.5 \pm 0.8^{\mathrm{ABCD}}$ & $2.1 \pm 1.1^{\mathrm{BCDEF}}$ & $2.1 \pm 1.3^{\mathrm{CDEFGH}}$ & $1.5 \pm 0.7^{\mathrm{C}}$ \\
\hline Carrot-3\% Cinnamaldehyde & $2.2 \pm 1.2^{\mathrm{CDEFG}}$ & $1.3 \pm 0.6^{\mathrm{ABCD}}$ & $2 \pm 1.2^{\mathrm{BCDEF}}$ & $2 \pm 1.1^{\mathrm{DEFGH}}$ & $1.8 \pm 1.0^{\mathrm{ABC}}$ \\
\hline Hibiscus 3\% Carvacrol & $2.5 \pm 1.3^{\mathrm{BCDEF}}$ & $1.8 \pm 1.1^{\mathrm{ABC}}$ & $2.6 \pm 1.3^{\mathrm{ABCDE}}$ & $2.5 \pm 1.3^{\mathrm{ABCDEF}}$ & $2.1 \pm 1.4^{\mathrm{ABC}}$ \\
\hline Apple-1.5\% Cinnamaldehyde & $2.6 \pm 1.2^{\mathrm{ABCDE}}$ & $1.1 \pm 0.3^{\mathrm{D}}$ & $2.1 \pm 1.2^{\mathrm{BCDEF}}$ & $2.4 \pm 1.3^{\mathrm{ABCDEF}}$ & $1.6 \pm 0.9^{\mathrm{BC}}$ \\
\hline Apple-3\% Cinnamaldehyde & $2.7 \pm 1.5^{\mathrm{ABCDE}}$ & $1.4 \pm 0.7^{\mathrm{ABCD}}$ & $1.7 \pm 1.1^{\mathrm{EF}}$ & $2.5 \pm 1.4^{\mathrm{ABCDEF}}$ & $1.6 \pm 1.0^{\mathrm{BC}}$ \\
\hline Carrot-1.5\% Carvacrol & $2.7 \pm 1.2^{\mathrm{ABCD}}$ & $1.5 \pm 0.7^{\mathrm{ABCD}}$ & $2.7 \pm 1.4^{\mathrm{ABCD}}$ & $2.7 \pm 1.3^{\mathrm{ABCDE}}$ & $2.1 \pm 1.2^{\mathrm{ABC}}$ \\
\hline Apple-3\% Carvacrol & $2.8 \pm 1.3^{\mathrm{ABCD}}$ & $1.8 \pm 0.9^{\mathrm{A}}$ & $2.4 \pm 1.3^{\mathrm{BCDEF}}$ & $2.5 \pm 1.2^{\mathrm{ABCDEF}}$ & $1.9 \pm 1.2^{\mathrm{ABC}}$ \\
\hline Carrot-3\% Carvacrol & $2.8 \pm 1.2^{\mathrm{ABCD}}$ & $1.8 \pm 1.0^{\mathrm{AB}}$ & $2.9 \pm 1.5^{\mathrm{ABC}}$ & $2.9 \pm 1.5^{\mathrm{ABCD}}$ & $2.4 \pm 1.4^{\mathrm{AB}}$ \\
\hline Hibiscus-1.5\% Cinnamaldehyde & $2.9 \pm 1.5^{\mathrm{ABCD}}$ & $1.2 \pm 0.4^{\mathrm{CD}}$ & $2.2 \pm 1.3^{\mathrm{BCDEF}}$ & $3.0 \pm 1.4^{\mathrm{ABC}}$ & $1.7 \pm 1.1^{\mathrm{BC}}$ \\
\hline Hibiscus-1.5\%Carvacrol & $3.0 \pm 1.3^{\mathrm{ABC}}$ & $1.5 \pm 0.8^{\mathrm{ABCD}}$ & $2.9 \pm 1.5^{\mathrm{AB}}$ & $2.8 \pm 1.4^{\mathrm{ABCD}}$ & $2.1 \pm 1.2^{\mathrm{ABC}}$ \\
\hline Hibiscus-3\% Cinnamaldehyde & $3.3 \pm 1.4^{\mathrm{AB}}$ & $1.3 \pm 0.8^{\mathrm{ABCD}}$ & $2.0 \pm 1.1^{\mathrm{CDEF}}$ & $3.2 \pm 1.5^{\mathrm{A}}$ & $2.1 \pm 1.4^{\mathrm{ABC}}$ \\
\hline Apple-1.5\% Carvacrol & $3.5 \pm 1.2^{\mathrm{A}}$ & $1.8 \pm 0.9^{\mathrm{A}}$ & $3.4 \pm 1.4^{\mathrm{A}}$ & $3.2 \pm 1.4^{\mathrm{AB}}$ & $2.6 \pm 1.5^{\mathrm{A}}$ \\
\hline
\end{tabular}

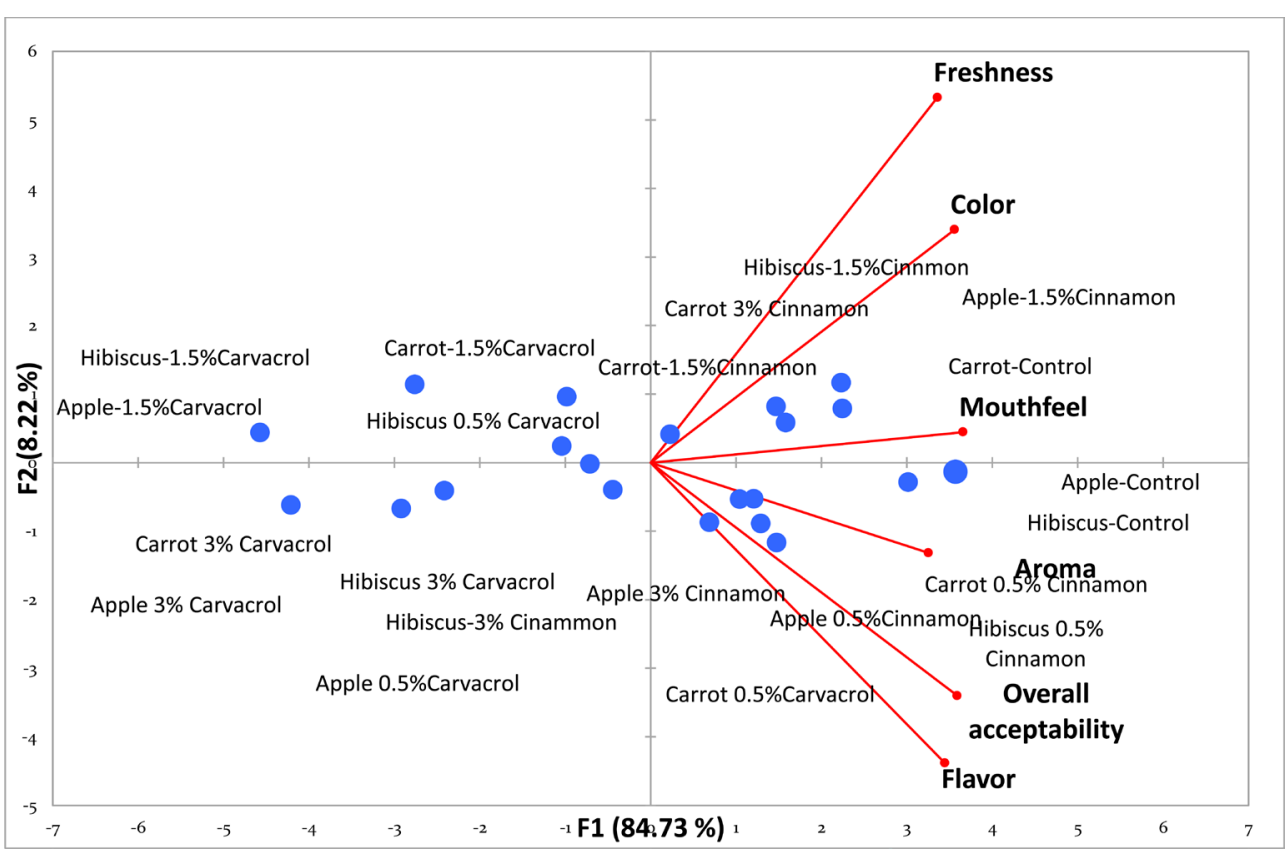

Figure 2. Principal Component Analysis (PCA) of preference liking for organic baby spinach treated with antimicrobial edible films after storage for $24 \mathrm{~h}$ at $4^{\circ} \mathrm{C}$. Preference liking was evaluated for aroma, color, freshness, mouthfeel, flavor, and overall acceptability based on a 9-point hedonic scale where 9-extremely liked, and 1-not liked at all. Data depicted is average of 40 responses for each sample.

The efficacy of essential oils against spoilage organisms and foodborne pathogens was concentration and time-dependent [16]; however, as shown in our studies, the preference liking decreases with the use of higher concentration of essential oils. Combination treatments can therefore be considered that could lead to a higher reduction in microbial counts and yet maintain sensory quality. A combination of oregano and rosemary oil at a sub-inhibitory concentration extended the shelf-life and improved safety of fresh vegetables [33]. There was no 
difference in preference liking between the three types of films. The types of essential oil incorporated into these films had a higher impact on the preference liking than the edible film material itself. Comparing the control films of apple, hibiscus, and carrot, the highest preference liking was for apple films; however, no significant difference ( $p>0.05$ ) was seen between the other two films.

The aroma rating ranged from $7.1 \pm 1.8$ (moderately liked) to $4.8 \pm 2.7$ (slightly disliked) and majority of the samples were ranked as slightly liked on the basis of the aroma property. There was no significant difference $(p>0.05)$ in preference liking of aroma between any samples except for carrot-3\% carvacrol, hibiscus- $1.5 \%$ carvacrol, and appple-1.5\% carvacrol, all of which had the lowest rating for aroma from $5.2 \pm 2.4$ (neither liked nor disliked) to $4.8 \pm 2.7$ (disliked slightly). The color of spinach was not impacted much by the addition of edible films as all the samples were ranked between $7.9 \pm 1.4$ (moderately liked) and 6.1 \pm 2.3 (slightly liked). The freshness quality of spinach was also ranked highly because majority of the samples were rated between 6 and 7 (slightly to moderately liked). The effect on mouthfeel was observed in the spinach sample treated with carrot-3\% carvacrol film because it had the lowest ranking of $4.7 \pm$ 2.8 (slightly disliked); however, most other samples were ranked between slightly and moderately liked. Flavor was the most impacted by the addition of these edible films with the preference ranking ranging from $7.1 \pm 1.9$ (moderately liked) to $3.5 \pm 2.5$ (moderately disliked). Overall, spinach treated with edible films containing cinnamaldehyde had a higher preference for flavor compared to those that included carvacrol. The rating of overall acceptability ranged from 7.1 \pm 1.7 (moderately liked) to $3.6 \pm 2.5$ (moderately disliked) and spinach treated with films containing cinnamaldehyde had higher preference liking compared to those treated with carvacrol films.

Panelists were also asked to quantify specific attributes noticed in each spinach sample based on pungency, browning, bitterness, off-odor, and sourness. Results regarding the impact of antimicrobial edible films on the sensory attributes of spinach samples are presented in Table 2 and Figure 3. The pungency level ranked from $3.5 \pm 1.2$ (moderately pungent) to $1.3 \pm 0.6$ (not pungent at all). In addition, there was a concentration dependency for pungency level because samples treated with edible films containing higher concentrations of either cinnamaldehyde or carvacrol were ranked higher for pungency. For majority of the samples, carvacrol was rated higher for pungency compared to cinnamaldehyde. All types of edible films did not have any adverse effect on the browning level on spinach because samples had a rating of 1 (not brown at all). Spinach treated with apple film-1.5\% carvacrol was rated the highest for bitterness at a rating of $3.4 \pm 1.4$ (moderately bitter) and the lowest bitterness rating was for spinach sample treated with apple-control films having a rating of $1.5 \pm$ 0.8 (not bitter at all). The highest off-odor was detected in spinach treated with hibiscus-3\% cinnamaldehyde and apple- $1.5 \%$ carvacrol films rated at $3.2 \pm 1.5$ (moderately off). The sourness ranking ranged from $1.3 \pm 0.06$ (not sour at all) 


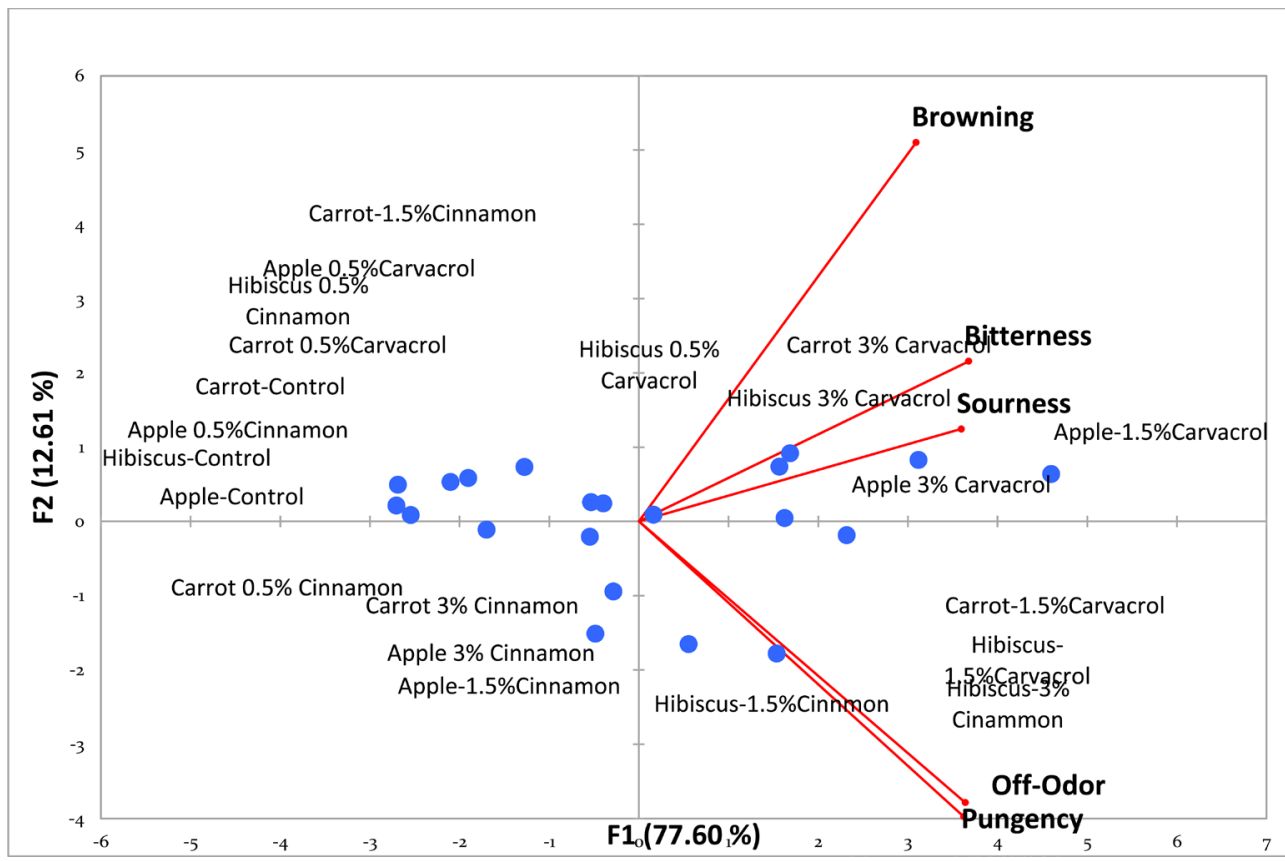

Figure 3. Principal Component Analysis of sensory characteristics of baby spinach stored at $4^{\circ} \mathrm{C}$ for $24 \mathrm{~h}$. Impact on sensory characteristics (pungency, browning, bitterness, off-odor, and sourness) were rated based on a 5-point hedonic scale with 5-highest impact and 1-no impact at all. Data depicted is an average response of 40 panelists for each sample.

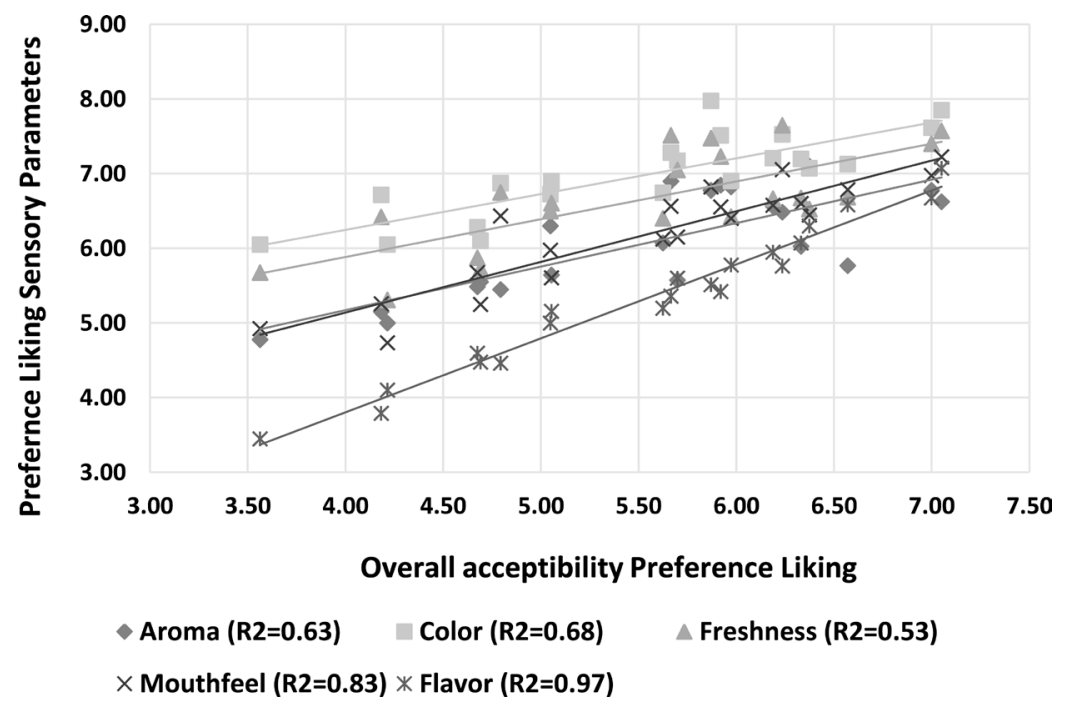

Figure 4. Linear correlation between values of average overall acceptability rating and other sensory parameters (aroma, freshness, mouthfeel, color, and flavor) for organic baby spinach treated with edible films containing plant antimicrobials.

for spinach treated with apple- $0.5 \%$ cinnamaldehyde and hibiscus- $0.5 \%$ carvacrol films to $2.6 \pm 1.5$ (slightly sour) for those treated with apple-1.5\% carvacrol films.

Linear regression (Figure 4) was conducted to compare the data on the ranking of overall acceptability with that of aroma, color, freshness, mouthfeel, and flavor. For edible film samples, the average rating for flavor $\left(\mathrm{R}^{2}=0.97\right)$ was 
closely related to the average rating of overall acceptability. This suggests that flavor was the most influencing factor in determining the overall acceptability of any spinach sample. A similar trend was seen where a correlation of $\mathrm{R}^{2}=0.91$ was found between flavor and overall acceptability of a salad dressing incorporated with $0.2 \%$ oregano essential oils and $1.14 \%$ salt [34]. Each panelist was asked how likely they are to purchase a particular sample and 19/40 mentioned very or extremely likely to purchase spinach treated with hibiscus-control and apple-control films (data not shown). The next highest rated sample for very or extremely likely to be purchased included spinach treated with carrot- $0.5 \%$ cinnamaldehyde films (16/40) (data not shown). A strong correlation of $\mathrm{R}^{2}=0.94$ was found between the rating of overall acceptability and the likelihood of purchasing a sample (data not shown).

A coating may not be an ideal use of edible films for leafy greens because a large surface area would need to be covered. Other studies have shown that coating applications could lead to a significant decrease in aroma and flavor of strawberries with edible films containing oleic acid and chitosan [12]. Therefore, in this study we incorporated pieces of edible films into salad bags rather than coating the entire spinach leaf. Additionally, it is important to determine what type of essential oils or plant extracts can be used and the concentration that may be incorporated into various types of food commodities. Some essential oils that are strong in flavor are used in meat or fish products. Concentrations of up to $100 \mu \mathrm{L} / \mathrm{L}$ of limonene (present in citrus essential oils), $150 \mu \mathrm{L} / \mathrm{L}$ of carvacrol, or $200 \mu \mathrm{L} / \mathrm{L}$ of lemongrass essential oil, or other citrus essential oils did not affect the sensory attributes of some fruit juices such as orange juice [35] [36].

\subsection{Principal Component Analysis (PCA)}

A software XLStat (New York, NY, USA) was used to analyze sensory data of preference liking and sensory characteristics of plant-antimicrobial edible films in spinach salad bags using principal component analysis (PCA). Two principal components PC1 and PC2 were generated for preference liking that accounted for $84.73 \%$ and $8.22 \%$ variance, respectively based on six variables (aroma, color, freshness, mouthfeel, flavor, and overall acceptability) (Figure 2). Again, PCA plots were used to analyze the impact of plant-antimicrobial edible films on sensory characteristics of spinach samples. Two components PCA 1 and PCA 2 were generated for sensory characteristics based on five variables (pungency, browning, bitterness, off-odor, and sourness), and accounted for $77.60 \%$ and $12.61 \%$ variance, respectively (Figure 3 ). In general, the highest preference liking was observed for samples with edible films containing cinnamaldehyde in comparison to those with carvacrol. In addition, a concentration-based dependency was seen where lower concentrations of essential oils in edible films showed higher preference liking. Samples with the highest preference liking were also rated low for sensory characteristics based on pungency, browning, bitterness, off-odor, and sourness. 


\subsection{Textural and Color Analysis}

The firmness values of treated and control baby spinach samples were measured using a Texture analyzer. Three separate trials were conducted for each sample and an average of the highest peak force required to completely crush the sample was indicated as its firmness or crispiness value (Table 3 ). There was no significant difference $(p>0.05)$ among all the edible films treated spinach samples based on their firmness value. Overall, edible films that contained cinnamaldehyde had a lower impact on the firmness values as suggested by higher force required to crush these samples than those that included carvacrol. For example, the highest firmness/crispiness value was observed for spinach treated with apple-1.5\% cinnamaldehyde film $(\mathrm{F}=889.8 \pm 52.9 \mathrm{~N})$, whereas the lowest firmness value was observed for spinach treated with hibiscus-3\% carvacrol film ( $\mathrm{F}=$ $643.3 \pm 60.7 \mathrm{~N}$ ).

Table 3. Crispiness values of organic baby spinach after storage at $4^{\circ} \mathrm{C}$ for $24 \mathrm{~h}$ in salad bags containing edible films with plant-antimicrobials. Crispiness values were measured by taking an average of the highest peak force $(\mathrm{N})$ required to crush the samples from three separate trials. Different letters signify statistical difference $(p \geq 0.05)$ between force values of each treatment.

\begin{tabular}{|c|c|}
\hline Treatments & Average Peak Force (N) \\
\hline Carrot Control & $80,075^{\mathrm{A}}$ \\
\hline Carrot $0.5 \%$ Cinnamaldehyde & $828 \pm 66^{\mathrm{A}}$ \\
\hline Carrot $1.5 \%$ Cinnamaldehyde & $876 \pm 78^{\mathrm{A}}$ \\
\hline Carrot 3\% Cinnamaldehyde & $848 \pm 26^{\mathrm{A}}$ \\
\hline Carrot $0.5 \%$ Carvacrol & $735 \pm 76^{\mathrm{A}}$ \\
\hline Carrot $1.5 \%$ Carvacrol & $867 \pm 75^{\mathrm{A}}$ \\
\hline Carrot 3\% Carvacrol & $735 \pm 17^{\mathrm{A}}$ \\
\hline Hibiscus Control & $749 \pm 62^{\mathrm{A}}$ \\
\hline Hibiscus $0.5 \%$ Cinnamaldehyde & $851.5 \pm 4.6^{\mathrm{A}}$ \\
\hline Hibiscus $1.5 \%$ Cinnamaldehyde & $780 \pm 110^{\mathrm{A}}$ \\
\hline Hibiscus 3\% Cinnamaldehyde & $880 \pm 120^{\mathrm{A}}$ \\
\hline Hibiscus $0.5 \%$ Carvacrol & $704 \pm 62^{\mathrm{A}}$ \\
\hline Hibiscus 1.5\% Carvacrol & $867 \pm 75^{\mathrm{A}}$ \\
\hline Hibiscus 3\% Carvacrol & $643 \pm 61^{\mathrm{A}}$ \\
\hline Apple Control & $735 \pm 76^{\mathrm{A}}$ \\
\hline Apple $0.5 \%$ Cinnamaldehyde & $720 \pm 120^{\mathrm{A}}$ \\
\hline Apple $1.5 \%$ Cinnamaldehyde & $890 \pm 53^{\mathrm{A}}$ \\
\hline Apple 3\% Cinnamaldehyde & $806 \pm 99^{\mathrm{A}}$ \\
\hline Apple $0.5 \%$ Carvacrol & $750 \pm 150^{\mathrm{A}}$ \\
\hline Apple 1.5\% Carvacrol & $827 \pm 49^{\mathrm{A}}$ \\
\hline Apple 3\% Carvacrol & $693 \pm 77^{\mathrm{A}}$ \\
\hline
\end{tabular}


A concentration-dependent activity due to antimicrobial edible films treatment on the firmness of spinach was not observed. However, spinach samples containing $1.5 \%$ of either carvacrol or cinnamaldehyde resulted in higher firmness values in comparison to $0.5 \%$ or $3 \%$ concentrations of each of these antimicrobials.

The results presented here indicate that the presence of certain concentrations of these antimicrobials is extremely important for how they will affect the organoleptic properties of baby spinach. The type of films used such as apple, hibiscus, or carrot did not have a major impact on the firmness values, but the essential oil active components (carvacrol or cinnamaldehyde) incorporated in these films had a greater impact on the firmness values.

Color properties of baby spinach were not adversely impacted by the addition of edible films, as no significant change $(\mathrm{p}>0.05)$ was indicated in the $\mathrm{L}^{*}, \mathrm{a}^{*}, \mathrm{~b}^{*}$ values compared to the controls (Table 4). Spinach leaves are much darker in color compared to other leafy greens; therefore, color properties may not be

Table 4. CIE $\mathrm{L}^{*}, \mathrm{a}^{*}, \mathrm{~b}^{*}$ coordinates measured using a Chroma meter for baby spinach treated with plant antimicrobials and stored at $4^{\circ} \mathrm{C}$ for $24 \mathrm{~h}$. Average values, which do not share the same letter, are significantly different $(\mathrm{p} \leq 0.05)$.

\begin{tabular}{|c|c|c|c|}
\hline Treatments & $\mathrm{L}^{*}$ & $a^{*}$ & $b^{*}$ \\
\hline Apple Control & $39.0 \pm 2.9^{\mathrm{BCD}}$ & $-14.1 \pm 1.7^{\mathrm{AB}}$ & $19.6 \pm 4.7^{\mathrm{AB}}$ \\
\hline Apple $0.5 \%$ Carvacrol & $38.3 \pm 2.4^{\mathrm{BCD}}$ & $-14.1 \pm 1.7^{\mathrm{AB}}$ & $19.2 \pm 2.9^{\mathrm{AB}}$ \\
\hline Apple 1.5\% Carvacrol & $39.0 \pm 3.1^{\mathrm{BCD}}$ & $-15.5 \pm 1.2^{\mathrm{B}}$ & $21.0 \pm 1.9^{\mathrm{AB}}$ \\
\hline Apple 3\% Carvacrol & $36.3 \pm 3.8^{\mathrm{D}}$ & $-14.7 \pm 1.5^{\mathrm{AB}}$ & $18.5 \pm 3.4^{\mathrm{AB}}$ \\
\hline Apple $0.5 \%$ Cinnamaldehyde & $39.8 \pm 1.7^{\mathrm{BCD}}$ & $-13.6 \pm 2.8^{\mathrm{AB}}$ & $18.7 \pm 5.0^{\mathrm{AB}}$ \\
\hline Apple $1.5 \%$ Cinnamaldehyde & $39.2 \pm 3.0^{\mathrm{BCD}}$ & $-14.4 \pm 2.3^{\mathrm{AB}}$ & $20.9 \pm 5.9^{\mathrm{AB}}$ \\
\hline Apple 3\% Cinnamaldehyde & $38.4 \pm 2.9^{\mathrm{BCD}}$ & $-13.7 \pm 1.5^{\mathrm{AB}}$ & $18.3 \pm 4.0^{\mathrm{AB}}$ \\
\hline Carrot Control & $39.8 \pm 3.3^{\mathrm{BCD}}$ & $-14.8 \pm 1.3^{\mathrm{AB}}$ & $20.0 \pm 2.3^{\mathrm{AB}}$ \\
\hline Carrot $0.5 \%$ Carvacrol & $38.6 \pm 2.6^{\mathrm{BCD}}$ & $-15.1 \pm 1.6^{\mathrm{AB}}$ & $20.5 \pm 3.0^{\mathrm{AB}}$ \\
\hline Carrot 1.5\% Carvacrol & $40.5 \pm 3.7^{\mathrm{BCD}}$ & $-14.3 \pm 1.7^{\mathrm{AB}}$ & $20.0 \pm 3.5^{\mathrm{AB}}$ \\
\hline Carrot 3\% Carvacrol & $42.8 \pm 4.0^{\mathrm{AB}}$ & $-13.0 \pm 1.6^{\mathrm{AB}}$ & $18.8 \pm 4.9^{\mathrm{AB}}$ \\
\hline Carrot $0.5 \%$ Cinnamaldehyde & $42.3 \pm 3.3^{\mathrm{AB}}$ & $-13.0 \pm 1.5^{\mathrm{AB}}$ & $18.0 \pm 2.8^{\mathrm{AB}}$ \\
\hline Carrot $1.5 \%$ Cinnamaldehyde & $40.9 \pm 3.3^{\mathrm{BCD}}$ & $-15.1 \pm 2.1^{\mathrm{AB}}$ & $21.3 \pm 4.0^{\mathrm{AB}}$ \\
\hline Carrot 3\% Cinnamaldehyde & $39.8 \pm 2.7^{\mathrm{BCD}}$ & $-13.5 \pm 1.7^{\mathrm{AB}}$ & $18.2 \pm 2.8^{\mathrm{AB}}$ \\
\hline Hibiscus Control & $40.5 \pm 1.5^{\mathrm{BCD}}$ & $-12.2 \pm 1.2^{\mathrm{A}}$ & $17.3 \pm 2.3^{\mathrm{B}}$ \\
\hline Hibiscus $0.5 \%$ Carvacrol & $42.0 \pm 3.5^{\mathrm{ABC}}$ & $-13.7 \pm 2.3^{\mathrm{AB}}$ & $19.7 \pm 3.8^{\mathrm{AB}}$ \\
\hline Hibiscus 1.5\% Carvacrol & $38.7 \pm 3.4^{\mathrm{BCD}}$ & $-14.5 \pm 1.6^{\mathrm{AB}}$ & $20.7 \pm 3.4^{\mathrm{AB}}$ \\
\hline Hibiscus 3\% Carvacrol & $36.8 \pm 3.4^{\mathrm{CD}}$ & $-13.4 \pm 2.5^{\mathrm{AB}}$ & $21.8 \pm 2.5^{\mathrm{AB}}$ \\
\hline Hibiscus $0.5 \%$ Cinnamaldehyde & $47.3 \pm 4.4^{\mathrm{A}}$ & $-14.0 \pm 1.5^{\mathrm{AB}}$ & $21.3 \pm 2.4^{\mathrm{AB}}$ \\
\hline Hibiscus $1.5 \%$ Cinnamaldehyde & $41.4 \pm 3.5^{\mathrm{BCD}}$ & $-15.9 \pm 2.1^{\mathrm{B}}$ & $23.6 \pm 3.5^{\mathrm{A}}$ \\
\hline Hibiscus 3\% Cinnamaldehyde & $38.4 \pm 3.4^{\mathrm{BCD}}$ & $-15.46 \pm 0.93^{\mathrm{AB}}$ & $21.5 \pm 1.7^{\mathrm{AB}}$ \\
\hline
\end{tabular}


impacted significantly. The $\mathrm{L}^{*}$ (light vs. dark) is the major value which may influence consumers' preference; however, for this value, the majority of the samples were not significantly $(\mathrm{p} \leq 0.05)$ different from the controls. The color properties of the films may be affected by the addition of essential oils as shown in other studies. For example, the addition of essential oils (at various concentrations) to apple puree caused an increase in the $\mathrm{L}^{*}$ value, $\mathrm{b}^{*}$ value and whitish index of the resulting edible films [28]. In our study, there was no adverse effect on the color properties of spinach leaves because the essential oils were incorporated into edible films, therefore, oils did not directly come in contact with the spinach leaves.

\section{Conclusion}

Our previous studies had indicated that the acceptable level of essential oils in wash water was $0.1 \%$; however, with the use of edible films the acceptable concentrations of essential oils can be increased to $0.5 \%$ or even $1.5 \%$, as we have shown in this study that spinach was acceptable at these concentrations. Spinach treated with films that contained cinnamaldehyde had a higher preference liking and less adverse effects on the sensory attributes (such as pungency, browning, off-odor, bitterness, and sourness) than those that included carvacrol. Spinach samples treated with films that included cinnamaldehyde were also more likely to be purchased than those samples treated with films containing carvacrol. Additionally, there was a concentration-dependent trend with regard to preference liking, as lower concentrations of antimicrobials in films had higher preference liking. Use of essential oils or plant extracts in produce wash water may affect the firmness and color properties of leafy greens (as shown in our previous studies); however, with the use of edible films, no significant change in firmness and color values was detected. This study provides an innovative way to incorporate plant antimicrobials in leafy green salads without adversely affecting the sensory quality. Sensory studies on other types of leafy greens such as iceberg and romaine lettuces treated with antimicrobial edible films merit further investigations.

\section{Acknowledgements}

This research was supported by the U.S. Department of Agriculture, National Institute of Food and Agriculture, Organic Research and Extension Initiative competitive grant no. 2010-51300-21760. The authors would like to thank The Food Technology Corporation for providing the Kramer shear probe for texture analysis and Mr. Drew Lambert for his technical assistance with the texture analysis. The authors also thank Libin Zhu of the Ravishankar laboratory for his technical assistance and training the graduate student on data analysis. Additionally, the authors like to thank Rena Shifren a sensory evaluation and consumer behavior specialist from Prosense Consumer and Research Center, Tucson, AZ, for her technical assistance with the sensory study and Carol Levin of USDA-WRRC, Albany, CA, for facilitating preparation of the manuscript. 


\section{Conflicts of Interest}

The authors declare no conflicts of interest regarding the publication of this paper.

\section{References}

[1] Burt, S. (2004) Essential Oils: Their Antibacterial Properties and Potential Applications in Foods-A Review. International Journal of Food Microbiology, 94, 223-253. https://doi.org/10.1016/j.ijfoodmicro.2004.03.022

[2] Friedman, M., Henika, P.R. and Mandrell, R.E. (2002) Bactericidal Activities of Plant Essential Oils and Some of Their Isolated Constituents against Campylobacter jejuni, Escherichia coli, Listeria monocytogenes, and Salmonella enterica. Journal of Food Protection, 65, 1545-1560. https://doi.org/10.4315/0362-028X-65.10.1545

[3] Roller, S. and Seedhar, P. (2002) Carvacrol and Cinnamic Acid Inhibit Microbial Growth in Fresh-Cut Melon and Kiwifruit at $4^{\circ}$ and $8^{\circ} \mathrm{C}$. Letters in Applied Microbiology, 35, 390-394. https://doi.org/10.1046/j.1472-765X.2002.01209.x

[4] Asensio, C.M., Nepote, V. and Grosso, N.R. (2012) Sensory Attribute Preservation in Extra Virgin Olive Oil with Addition of Oregano Essential Oil as Natural Antioxidant. Journal of Food Science, 77, S294-S301. https://doi.org/10.1111/j.1750-3841.2012.02841.X

[5] Karabagias, I., Badeka, A. and Kontominas, M.G. (2011) Shelf Life Extension of Lamb Meat Using Thyme or Oregano Essential Oils and Modified Atmosphere Packaging. Meat Science, 88, 109-116. https://doi.org/10.1016/j.meatsci.2010.12.010

[6] Gutierrez, J., Barry-Ryan, C. and Bourke, P. (2009) Antimicrobial Activity of Plant Essential Oils Using Food Model Media: Efficacy, Synergistic Potential and Interactions with Food Components. Food Microbiology, 26, 142-150. https://doi.org/10.1016/j.fm.2008.10.008

[7] Du, W.X., Olsen, C.W., Avena-Bustillos, R.J., McHugh, T.H., Levin, C.E. and Friedman, M. (2008) Storage Stability and Antibacterial Activity against Escherichia coli O157: H7 of Carvacrol in Edible Apple Films Made by Two Different Casting Methods. Journal of Agricultural and Food Chemistry, 56, 3082-3088. https://doi.org/10.1021/jf703629s

[8] Bourtoom, T. (2008) Edible Films and Coatings: Characteristics and Properties. International Food Research Journal, 15, 237-248.

[9] Vojdani, F. and Torres, J.A. (1990) Potassium Sorbate Permeability of Methylcellulose and Hydroxypropyl Methylcellulose Coatings: Effect of Fatty Acids. Journal of Food Science, 55, 841-846. https://doi.org/10.1111/j.1365-2621.1990.tb05244.x

[10] Cuppett, S.L. (1994) Edible Coatings as Carriers of Food Additives, Fungicides and Natural Antagonists. In: Krochta, J.M., Baldwin, E.A. and Nisperos-Carriedo, M.O. Eds., Edible Coatings and Films to Improve Food Quality, CRC Press, Boca Raton, 121-137.

[11] Yaman, Ö. and Bayindirli, L. (2001) Effects of an Edible Coating, Fungicide and Cold Storage on Microbial Spoilage of Cherries. European Food Research and Technology, 213, 53-55. https://doi.org/10.1007/s002170100334

[12] Vargas, M., Albors, A., Chiralt, A. and González-Martínez, C. (2006) Quality of Cold-Stored Strawberries as Affected by Chitosan-Oleic Acid Edible Coatings. Postharvest Biology and Technology, 41, 164-171. https://doi.org/10.1016/j.postharvbio.2006.03.016

[13] Coma, V., Martial-Gros, A., Garreau, S., Copinet, A., Salin, F. and Deschamps, A. (2002) Edible Antimicrobial Films Based on Chitosan Matrix. Journal of Food 
Science, 67, 1162-1169. https://doi.org/10.1111/j.1365-2621.2002.tb09470.x

[14] Valencia-Chamorro, S.A., Palou, L., Delŕio, M.A. and Pérez-Gago, M.B. (2011) Antimicrobial Edible Films and Coatings for Fresh and Minimally Processed Fruits and Vegetables: A Review. Critical Reviews in Food Science and Nutrition, 51, 872-900. https://doi.org/10.1080/10408398.2010.485705

[15] Labuza, T.P. and Breene, W.M. (1989) Applications of "Active Packaging" for Improvement of Shelf-Life and Nutritional Quality of Fresh and Extended Shelf-Life Foods. Journal of Food Processing and Preservation, 13, 1-69. https://doi.org/10.1111/j.1745-4549.1989.tb00090.x

[16] Moore-Neibel, K., Gerber, C., Patel, J., Friedman, M., Jaroni, D. and Ravishankar, S. (2013) Antimicrobial Activity of Oregano Oil against Antibiotic-Resistant Salmonella enterica on Organic Leafy Greens at Varying Exposure Times and Storage Temperatures. Food Microbiology, 34, 123-129. https://doi.org/10.1016/j.fm.2012.12.001

[17] Todd, J., Friedman, M., Patel, J., Jaroni, D. and Ravishankar, S. (2013) The Antimicrobial Effects of Cinnamon Leaf Oil against Multi-Drug Resistant Salmonella Newport on Organic Leafy Greens. International Journal of Food Microbiology, 166, 193-199. https://doi.org/10.1016/j.ijfoodmicro.2013.06.021

[18] De Azerêdo, G.A., De Figueiredo, R.C.B.Q., De Souza, E.L. and Stamford, T.L.M. (2012) Changes in Listeria monocytogenes Induced by Origanum vulgare L. And Rosmarinus officinalis L. Essential Oils Alone and Combined at Subinhibitory Amounts. Journal of Food Safety, 32, 226-235. https://doi.org/10.1111/j.1745-4565.2012.00372.x

[19] Kester, J.J. and Fennema, O.R. (1986) Edible Films and Coatings: A Review. Food Technology, 40, 47-59.

[20] Rojas-Grä̈, M.A., Avena-Bustillos, R.J., Friedman, M., Henika, P.R., Martin-Belloso, O. and McHugh, T.H. (2006) Mechanical, Barrier, and Antimicrobial Properties of Apple Puree Edible Films Containing Plant Essential Oils. Journal of Agricultural and Food Chemistry, 54, 9262-9267. https://doi.org/10.1021/jf061717u

[21] Rojas-Graü, M.A., Avena-Bustillos, R.J., Olsen, C., Friedman, M., Henika, P.R., Martín-Belloso, O., et al. (2007) Effects of Plant Essential Oils and Oil Compounds on Mechanical, Barrier and Antimicrobial Properties of Alginate-Apple Puree Edible Films. Journal of Food Engineering, 81, 634-641.

https://doi.org/10.1016/j.jfoodeng.2007.01.007

[22] Ravishankar, S., Jaroni, D., Zhu, L., Olsen, C.W., McHugh, T.H. and Friedman, M. (2012) Inactivation of Listeria monocytogenes on Ham and Bologna Using Pectin-Based Apple, Carrot, and Hibiscus Edible Films Containing Carvacrol and Cinnamaldehyde. Journal of Food Science, 77, M377-M382.

https://doi.org/10.1111/j.1750-3841.2012.02751.x

[23] Zhu, L., Olsen, C., McHugh, T., Friedman, M., Jaroni, D. and Ravishankar, S. (2014) Apple, Carrot, and Hibiscus Edible Films Containing the Plant Antimicrobials Carvacrol and Cinnamaldehyde Inactivate Salmonella Newport on Organic Leafy Greens in Sealed Plastic Bags. Journal of Food Science, 79, M61-M66. https://doi.org/10.1111/1750-3841.12318

[24] Zhu, L., Olsen, C., McHugh, T., Friedman, M., Levin, C.E., Jaroni, D., et al. (2020) Edible Films Containing Carvacrol and Cinnamaldehyde Inactivate Escherichia coli O157: H7 on Organic Leafy Greens in Sealed Plastic Bags. Journal of Food Safety, 40, ee12758. https://doi.org/10.1111/jfs. 12758

[25] Espina, L., García-Gonzalo, D. and Pagán, R. (2014) Impact of Essential Oils on the 
Taste Acceptance of Tomato Juice, Vegetable Soup, or Poultry Burgers. Journal of Food Science, 79, S1575-S1583. https://doi.org/10.1111/1750-3841.12529

[26] de Sousa, J.P., Torres, R.A., de Azerêdo, G.A., Figueiredo, R.C.B.Q., Vasconcelos, M.A.S. and de Souza, E.L. (2012) Carvacrol and 1,8-Cineole Alone or in Combination at Sublethal Concentrations Induce Changes in the Cell Morphology and Membrane Permeability of Pseudomonas fluorescens in a Vegetable-Based Broth. International Journal of Food Microbiology, 158, 9-13.

https://doi.org/10.1016/j.ijfoodmicro.2012.06.008

[27] Martín-Diana, A.B., Rico, D., Frías, J., Henehan, G.T.M., Mulcahy, J., Barat, J.M., et al. (2006) Effect of Calcium Lactate and Heat-Shock on Texture in Fresh-Cut Lettuce during Storage. Journal of Food Engineering, 77, 1069-1077.

https://doi.org/10.1016/j.jfoodeng.2005.08.037

[28] Du, W.X., Olsen, C.W., Avena-Bustillos, R.J., McHugh, T.H., Levin, C.E. and Friedman, M. (2009) Effects of Allspice, Cinnamon, and Clove Bud Essential Oils in Edible Apple Films on Physical Properties and Antimicrobial Activities. Journal of Food Science, 74, M372-M378. https://doi.org/10.1111/j.1750-3841.2009.01282.x

[29] Barrett, D.M., Beaulieu, J.C. and Shewfelt, R. (2010) Color, Flavor, Texture, and Nutritional Quality of Fresh-Cut Fruits and Vegetables: Desirable Levels, Instrumental and Sensory Measurement, and the Effects of Processing. Critical Reviews in Food Science and Nutrition, 50, 369-389. https://doi.org/10.1080/10408391003626322

[30] Du, W.-X., Olsen, C.W., Avena-Bustillos, R.J., Friedman, M. and McHugh, T.H. (2011) Physical and Antibacterial Properties of Edible Films Formulated with Apple Skin Polyphenols. Journal of Food Science, 76, M149-M155. https://doi.org/10.1111/j.1750-3841.2010.02012.x

[31] Trezza, T.A. and Krochta, J.M. (2000) The Gloss of Edible Coatings as Affected by Surfactants, Lipids, Relative Humidity, and Time. Journal of Food Science, 65, 658-662. https://doi.org/10.1111/j.1365-2621.2000.tb16068.x

[32] Joshi, K. (2016) Evaluating the Effects of Organic Sanitizers and Plant: Antimicrobials on Harvesting Equipment and Sensory Properties of Organic Leafy Greens. Master's Thesis, University of Arizona, Tucson.

[33] de Medeiros Barbosa, I., da Costa Medeiros, J.A., de Oliveira, K.T.R., Gomes-Neto, N.J., Tavares, J.F., Magnani, M., et al. (2016) Efficacy of the Combined Application of Oregano and Rosemary Essential Oils for the Control of Escherichia coli, Listeria monocytogenes and Salmonella Enteritidis in Leafy Vegetables. Food Control, 59, 468-477. https://doi.org/10.1016/j.foodcont.2015.06.017

[34] Cattelan, M.G., de Castilhos, M.B.M., da Silva, D.C.M.N., Conti-Silva, A.C. and Hoffmann, F.L. (2015) Oregano Essential Oil: Effect on Sensory Acceptability. Nutrition \& Food Science, 45, 574-582. https://doi.org/10.1108/NFS-02-2015-0014

[35] Raybaudi-Massilia, R.M., Mosqueda-Melgar, J., Soliva-Fortuny, R. and Martín-Belloso, O. (2009) Control of Pathogenic and Spoilage Microorganisms in Fresh-Cut Fruits and Fruit Juices by Traditional and Alternative Natural Antimicrobials. Comprehensive Reviews in Food Science and Food Safety, 8, 157-180. https://doi.org/10.1111/j.1541-4337.2009.00076.x

[36] Espina, L., Condón, S., Pagán, R. and García-Gonzalo, D. (2014) Synergistic Effect of Orange Essential Oil or (+)-Limonene with Heat Treatments to Inactivate Escherichia coli $\mathrm{O} 157: \mathrm{H} 7$ in Orange Juice at Lower Intensities While Maintaining $\mathrm{He}$ donic Acceptability. Food and Bioprocess Technology, 7, 471-481.

https://doi.org/10.1007/s11947-013-1076-x 